\title{
The New Merger Guidelines: An Afterword
}

\author{
Lawrence A. Sullivan†
}

I

\section{The Guidelines and the Legal Tradition}

Antitrust can be understood as an aspect of regulation-an encounter between governance and the economy. So viewed, it must be expected to respond to changes in political and social attitudes. Indeed, one can view many antitrust developments as the result of the pushing and hauling that goes on between those who fear the bureaucratic corporation more than the bureaucratic state, and those whose priority of concerns is the reverse. ${ }^{1}$ When many in government thought that modern corporate development was producing concentrations of economic power "coinpet[img] on equal terms with the modern state,"2 antitrust reflected that perspective. Today those responsible for antitrust regard economic efficiency as the overarching need and unconstrained markets as the best mechanism for attaining that efficiency. Antitrust is being cut to a new pattern.

Antitrust, however, is not merely regulation. Congress decided in 1890 to maintain competition through rights and obligations enforced by the courts, a decision reinforced from time to time and modified only in ininor respects. The uniqueness of this tradition is often noted. There are marked substantive differences between American antitrust law and the ways in whicl European nations confronted the twentieth century economy - the dirigiste tradition in France, the tradition of corporatisin in Germany, and the tradition of entrepreneurial freedom in England. ${ }^{3}$ But it bears even greater emphasis that in antitrust, government uses law rather than administration to infiuence the economy. Indeed, observers used to describe the Antitrust Division as a law enforcement agency; it would investigate, prosecute and pray for judg-

$\dagger$ Earl Warren Professor of Public Law, Boalt Hall School of Law, University of California, Berkeley. B.A. 1948, University of Cahfornia, Los Angeles; J.D. 1951, Harvard University.

1. Cf. D. Boorstin, The AMERICANs 413-22 (1973) (political leaders feared the power of the corporations); R. WeIBE, THE SEARCh FOR ORDER, 1877-1920, at $52-54$ (1967) (antitrust served to control corporate threats to local autonomy).

2. A. Berle \& G. Means, The Modern Corporation and Private Property 313 (rev. ed. 1968).

3. Keller, The Pluralist State: American Economic Regulation in Comparative Perspective, 1900-1930, in Regulation in Perspective 56, 59-69 (T. McCraw ed. 1981). 
ment. ${ }^{4}$ Some of Assistant Attorney General Baxter's statements suggest that he sees his function more like that of the European administrator, free to start fresh on his own tack. ${ }^{5}$ Thus, he weighs, measures, and renders judgment-functions his predecessors have exercised within the conventional confines of prosecutorial discretion. In addition, however, when he believes the law should be changed-as in the case of the per se rule against resale price fixing-he is loath to enforce it. ${ }^{6}$ It is perhaps this aspect of Baxter's incumbency to which the skepticism found in some of the articles in this collection responds.

The recognition that antitrust is law and not free-form policy has implications that are discussed in several of the articles contributed to this Symposiun. ${ }^{7}$ Law has its own values, however imperfectly achieved-values which administration in the European sense may more easily ignore. For example, when Areeda reminds us of the diffculties of attaining clarity in antitrust, he also reminds us that clarity is an important goal. ${ }^{8}$ Other goals are equally important, though often harder to attain. The European tradition allows demands made by government on economic actors to be based on current thought and analysis and to speak prospectively. ${ }^{9}$ Because antitrust is a system of law, the norm announced today may be used to evaluate yesterday's conduct as well, and cannot be so easily modified if experience suggests deficiencies. In such a system, those who announce policy must have an eye for certainty, predictability, continuity, and consistency ${ }^{10}$-aspi-

4. See S. Weaver, Decision to Prosecute: Organization and Public Policy in the ANTITRUST Division 48-54 (1977).

5. The distinction between the European adininistrative tradition and the American legal tradition in antitrust is examined in detail in J. Maxeiner, Policy aud Methods in German and American Antitrust Law: Soine Comparative Observations 7-53 to 7-59 (June 24, 1982) (unpublished doctoral dissertation, Law Faculty, Ludwig-Maximilian University, Munich, Federal Republic of Germany) (on file at California Law Review).

6. See, e.g., Kramer, Antitrust Today: The Baxterization of the Sherman and Clayton Acts, 1981 Wis. L. REv. 1287, 1287-1300, and the Baxter statements cited by Schwartz in his contribution to this Symposium. Schwartz, The New Merger Guidelines: Guide to Governmental Discretion and Private Counseling or Propaganda for Revision of the Antitrust Laws?, 71 CALIF. L. REv. 575, 577 n.10, 578 n.14 (1983). There have, of course, been earlier efforts at radical transformation of the antitrust laws. Herbert Hoover was the author of one. Hawley, Three Facets of Hooverian Associationalism: Lumber, Aviation, and Movies, 1921-1930, in Regulation in Perspective 95123 (T. McCraw ed. 1981). Thurman Arnold was the author of quite a different one. Arnold's effort to convert antitrust from an unrelated series of inodest responses to episodic complaints about business conduct to a systematic program to end excessive pricing and supression of innovation on an industry-wide basis is engagingly told in R. HofsTADTER, What Happened to the Antitrust Movement?, in The Paranoid Style in American Politics and Other Essays 188, 19194, 228-32 (1966).

7. See, e.g., Schwartz, supra note 6, at 577-78.

8. See Areeda, Justice's Merger Guidelines: The General Theory, 71 CaLIf. L. Rev. 303, 30304 (1983).

9. See J. Maxeiner, supra note 5, at 1-12.

10. L. Sullivan, HaNDBooK OF THE LAW OF ANTITRUST \& 2, at 13 (1977). 
rations that the Guidelines might ideally serve.

Of course law, though untouched by Congress, can change over time through reasoned judicial elaboration. Indeed, when dealing with antitrust statutes, which are broad, alnost constitutional in concept and language, the ongoing process of interpretation can unore appropriately extend beyond the original Congressional purpose than could the construction of less spacious statutes. An antitrust court nay pass Congressional values through the prisin of current economic information and current economic understanding. It may perhaps go further and introduce, into concepts like "restraint of trade" or "substantially to lessen coinpetition," values that have a higher order of significance at the time that a court makes its decision than they had when the legislature voted. ${ }^{11}$

Yet, no inore in antitrust than in other substantive areas are the courts molding soft clay. The process is developinental, organic. Both courts and enforcenent officials owe fealty to the premises and the values that Congress intended the legislation to express. Each new adininistration is entitled to its policy preferences, and may express these in appropriate ways. New antitrust initiatives, however, ought to be evaluated against a legal tradition. Thus, the articles in this Symposiun appropriately ask how effectively the Guidelines integrate the administration's policy preferences with existing law. How well do the Guidelines fare?

II

HORIZONTAL MERGERS

\section{A. The Values Underlying the Guidelines}

It is horizontal inergers that the Guidelines treat seriously. With differing einphases, several of the articles ${ }^{12}$ call attention to elements of both developinent and continuity between the horizontal Merger Guidelines and prior law. Kauper, for example, notes that the Division has raised concentration thresholds and also that efficiency is now the only enforceinent goal. ${ }^{13}$ Nevertheless, he shows that the threshold in-

11. Freund, The Humanities and the Constitution, HARv. L. SCH. BuLL. Fall 1982, at 22, 23, remarks on the

ongoing debate on ... whether an understanding of the Constitution is essentially a matter of imterpreting its language to produce the results that we think the Framers would have reached, or taking account of the values implicit in its premises and structure, or incorporating into its spacious clauses the values most significant today.

Similar issues are encountered in the search for meaning in the antitrust laws.

12. E.g., Kauper, The 1982 Horizontal Merger Guidelines: Of Collusion, Efficiency and Fallure, 7 I CALIF. L. REv. 497, 505 (1983); Baker \& Blumenthal, The 1982 Guidelines and Preexisting Law, 71 CaLIF. L. Rev. 311,332 (1983).

13. Kauper, supra note 12 , at $498-99,511$. 
crease is modest, and that the exclusion of nonefficiency factors was anticipated if not openly adopted as early as the 1968 Guidelines. ${ }^{14}$ Kauper also tells us, as do others, ${ }^{15}$ that the Herfindahl-Hirschman Index (HHI) raises no issue of principle. ${ }^{16}$ It is a refinement of modest significance.

Despite its limited practical effect, the use of the $\mathrm{HHI}$ as a measure of concentration may teach something about the spirit with which the Division approached its task. Baker and Blumenthal regard the Guidelines as rejecting any relationship between concentration and peformance that is not exphicable on the inference of collusion, expressed or implied. ${ }^{17}$ They read earlier statements of policy as assumimg a direct but unexplamed relationship between concentration and profits-as it were, the "black box."18 I have always supposed that the risk of collusion or interdependence was behind concerns about concentration. In any event, in the on-going battle between economists who find a socially significant relationship between concentration and profits and those who do not, ${ }^{19}$ the HHI should appeal most to those who seek a new synthesis.

- Pautler makes a powerful contribution to this position. ${ }^{20} \mathrm{He}$ suggests that supracoinpetitive profits, inexphicable on efficiency grounds, may be an outcoine associated with possession of a large market share in a concentrated market (with high entry barriers), even though small firms in such a market may earn only nornal profits. If this is true, inergers of relatively small-share firms, even in highly concentrated markets, may present less of a problem than was previously believed. Mergers increasing the share of large firms in such markets remain a source of concern, however, quite independently of whether one can see within the black box by explaining low concentration leads to poor performance. Switching from concentration ratios to the HHI will, in any event, shift attention away froin inergers of the small-share type without reducing the impact of section 7 on inergers that increase the share of large firms. In this sense, the use of the index can be viewed as an effort to take the "new econormic learning" into account, without allowing it to overwhelin the established law.

14. Id. at 511-12.

15. See, e.g., Calkins, The New Merger Guidelines and The Herfindahl-Hirschman Index, 71 CALIF. L. Rev. 402, 428 (1983).

16. Kauper, supra note 12, at 511-12.

17. Baker \& Blumenthal, supra note 12 , at $\mathbf{3 1 6}$.

18. Id.

19. The literature is cited in Kauper, supra note 12, at 503 n.17. Gale \& Branch, Concentration Versus Market Share: Which Determines Performance and Why Does it Matter?, 27 ANTITRUST BuLl. 83 (1982) seems to be the latest entrant in the debate.

20. P. Pautler, A Review of the Economic Basis for Broad-Based Horizontal Merger Policy (July 1982) (unpublished manuscript to be published in the ANTITRUST BULL.). 
Baker and Blumenthal address the issue of values in a more polemic manner than does Kauper. ${ }^{21}$ In the Guideline's emphasis on effciency they discern a movement away from "populist" and toward "economic" values. As Harris and Jorde remind us, however, economic matters include more than efficiency. ${ }^{22}$ To assuune otherwise is to assign all save the most ardent Chicagoans to a ragged army of "populists." For example, to stress the distributional consequences of market power, as do Harris and Jorde, is to stress an economic issue that was of great concern to Congress, ${ }^{23}$ even though Chicagoans may give it scant attention. So too, Congressional concerns about free access to markets, ${ }^{24}$ and concern about managerial discretion to make significant decisions unconstramed by government regulation are not populist, in any neaningful historic sense, nor are they noneconomic. These are important economic issues, whether or not microtheory provides rigorous techniques for evaluating them.

\section{B. Concentration and the Guidelines}

The Guidelines arguably nnake too much of the new skepticism about the social significance of high concentration. Some of the articles in this Synposium reinark on the modest size of the change in thresholds, but say little about the direction of the change. The significance of particular thresholds depends, of course, upon the way markets are defined. The Guidelines' approach to defining the relevant market tends to magnify the increase in concentration thresholds, a matter on whicl several articles have unucl to say. ${ }^{25}$ But even assuming an unclianged methodology for market definition, and perhaps putting aside a few ill-decided cases, ${ }^{26}$ there is no coinpelling reason to conclude that the concentration levels responded to under existing law have systematically overestimated niarket power. ${ }^{27}$ Markets differ materially from each other. The significance of any given market share varies not only with how the market is defined, but also with other factors. ${ }^{28}$ One can

21. Compare Baker \& Blumenthal, supra note 12, at 311 ("Guidelines retreat significantly from many populist inerger landmarks of the Warren Court era") with Kauper, supra note 11, at 503 (in some respects, the Guidelines simply reflect changes which have already occurred).

22. Harris \& Jorde, Market Definition in the Merger Guidelines: Implications for Antitrust Enforcement, 71 CALIF. L. REv. 464, $465-66$ (1983).

23. See Fisher \& Lande, Efficiency Considerations in Merger Enforcennent, forthcoming in 92 YALE L.J. - (1983) (on file at California Law Review).

24. Congress sought "to preserve the chances of the average inan to inake a place for himself in busmess." 95 Cong. Rep. 11,506 (1949) (remarks of Rep. Bennett).

25. See, e.g., Harris \& Jorde, supra note 22.

26. E.g., United States v. Von's Grocery Co., 384 U.S. 270 (1966), criticized in L. SullivaN, supra note 10, § 204(b), at 618-19 (1977).

27. This point is argued effectively in Kaplow, The Accuracy of Traditional Market Power Analysis and a Direct Adjustment Alternative, 95 HARv. L. Rev. 1817, 1819-21 (1982).

28. Id. at 1819. 
surely say that inferring power from an analysis of market share is inevitably a simplification, and that there will be a band of error around any Guideline threshold. The fact remams, however, that no one has yet presented a basis for concluding that the simphifications of the decided cases are systematically biased in the direction of overestimating market power; the opposite conclusion is equally plausible.

Perhaps the Division's justification for increasing thresholds is its conviction that mergers may yield efficiences. The enormities that would be involved in a case-by-case analysis of efficiencies have been elaborated upon elsewhere. ${ }^{29}$ First, measurement problems defy solution. Second, even if one could predict both postmerger reductions in the marginal cost of output and the postmerger "dead weight" loss resulting from increased inarket power, and thus in a particular case show that the "welfare gam" froin efficiency outweighed the "welfare loss" from market power, little would be achieved. The "welfare" effect would alınost inevitably be swamped by distributional consequences. ${ }^{30}$

The Guidelines' theory may be that inability to do a case-by-case efficiency analysis warrants raising thresholds. If, overall, fewer mergers are challenged, arguably fewer efficiencies will be lost. If this notion is the basis of the Guideline thresholds, however, the Division is naking a blind tradeoff. It is following an imtuition about what is happening in the marketplace for which neither theory, einpirical data, legislative history, nor case law provide support. Indeed, the same factors that make it impossible to determine whether a particular merger yields greater efficiency gains than dead weight losses also make it useless to speculate about the effects of the inerger on the market. Furthermore, if mergers tend to inake inarkets function more efficiently in the aggregate, there is no obvious basis for assuming that the "good" mergers (those that on balance yield more efficiency than dead weight loss) are those near the low end of the concentration threshold.

If efficiencies can be achieved at all from horizontal inergers, they probably come from experience curve effects, the spreading of set-up costs over long production runs, consumer preferences for the market leader, and scale economies in working capital, marketing, and research and developinent. ${ }^{31}$ Some of these advantages can better be described as inarket failures rather than as efficiencies. For example, the assumption that it is "safer" to buy a computer from the firm with the largest inarket share, or that it is "safer" to lend money to such a firm, is a species of information failure. There may be little that can be done

29. Fisher \& Lande, supra note 23.

30. Id.

31. See, e.g., Gale \& Branch, supra note 19 , at 84-85. 
about these aspects of markets; yet, policies that tend to reduce concentration and that might reduce market share disparities would presumably be a move im the riglt direction. The poimt I wish to make here is that even if one regards effects like those listed above as efficiencies, they are likely to be attamed only througl mergers leadimg to large market shares. Raising thresholds to the extent done in the Guidelines will do little if anything to bring thein about. Fimally, if sucl "welfare" gams could be attained by raismg Guideline thresholds, they too would likely be overwhelined by the distributional effects of market power.

It is at points like these that some of the economic goals that are not captured by Chicago microtlieory become relevant. There is general agreement that excessive concentration may result im market power, leading to supracompetitive prices that transfer wealth from consumers to inonopolists. But Congress clearly wanted to stop that process in its incipiency. Doing so may also further other economic goals, such as facilitatimg entry and limiting the scope of managerial discretion that is not already constrained by impersonal market forces. Absent any credible basis for concludimg that the thresholds the courts have been using are eitler lower than needed to meter mcipient market power, or so low as to mipose significant efficiency costs, these related goals argue agamst eitler reducing thresholds or making changes in market definition inethodology that have the same effect.

\section{Market Definition and the Guidelines}

Harris-Jorde, ${ }^{32}$ Ordover-Willig, ${ }^{33}$ Baker-Blumenthal, ${ }^{34}$ and Schwartz ${ }^{35}$ all emphasize the significance of market definition. Here the Guidelines are inost innovative in techinique and-if the skepticism of some commentators is to be credited-here the Division's revisionist tendencies threaten results notably different froin those existing law would sanction. Indeed, as Harris-Jorde and Sclrwartz indicate, revisionism in market definition would affect not only merger enforcement but also inonopolization cases and rule of reason enforcement under section 1 of the Sherinan Act. ${ }^{36}$

Elsewhere I have argued that the law should state its critical concepts in its own terms, that concepts from economics like "market definition" ought not to be converted into legal categories. ${ }^{37}$ Competing theoretic formulations then could play through the legal system in the

32. Harris \& Jorde, supra note 22.

33. Ordover \& Willig, The 1982 Department of Justice Merger Guidelines: An Economic Assessment, 71 CALIF. L. REv. 534, 539 (1983).

34. Baker \& Blumenthal, supra note 12, at 323.

35. Schwartz, supra note 6, at 583-95.

36. Id. at 578; Harris \& Jorde, supra note 22, at 491-93.

37. L. Sullivan, supra note $10, \S 12$, at 41. 
form of expert analysis. The law would not be locked into a single theoretical view. As economic theory developed and changed, decisionmakers in particular cases could respond without revision of substantive legal doctrine.

Today the diagnosis of market power by defining markets and computing shares (or HHI indices) is under attack from several different directions. On the need for change Schwartz, Baker-Blumenthal, Davidson and Ordover-Willig all find common ground. ${ }^{38}$ Others have argued the inadequacy of market definition as a guide to power even more comprehensively. Schmalensee, for example, asserts that market definition lacks adequate quantitative foundations, rests on oversmiplified assumptions, cannot be improved by simple adjustments, yields only short run information, and may im some instances produce no information of value at all. ${ }^{39}$

Davidson's is perhaps the most novel perspective presented here. He suggests, in essence, that "niching behavior"-one of the conventional approaches of those who plan market strategy - can be a way of dividing seemingly homogeneous markets and avoiding competition within conventionally defined markets. ${ }^{40}$ The inore general message is that antitrust enforcers must remain inforined about new ways managers are conceptualizing. Strategic planners effect how decisions are made. It is appropriate that new strategies be evaluated with an eye to their impact on public, as well as corporate, welfare.

If one conceded that the Congressional goal expressed in section 7 transcended the economist's goal of "consumer welfare"-if, for example, one were convinced that Congress wanted to maintain markets of many sinall firms, regardless of effects on costs and prices ${ }^{41}$-then one might justify the use of market definition and concentration ratios as primary legal categories. Conversely, if section 7 is to be aimed solely or even primarily at consumer welfare, ideal legal categories would be sufficiently spacious so that alternative modes of economic analysis could be utilized.

Yet, given the present state of the law, the Guidelines' presupposition that market definition is a crucial part of the process camiot be

38. Schwartz, supra note 6, at 582; Baker \& Blumenthal, supra note 12, at 330-31; Davidson, The Competitive Significance of Competitive Markets, 71 CALIF. L. REv. 445, 446-47 (1983); Ordover \& Willig, supra note 33, at 558-59.

39. Schmalensee, Another Look at Market Power, 95 HARv. L. Rev. 1789, 1798-1804 (1982).

40. Davidson, supra note 38 , at 454-57 (1983).

41. The legislative history suggests a multiplicity of goals. The most important was control over the distributional effects of market power, in order to minimize shifts of resources from consumers to inonopolists. Others included blocking incipient increases im concentration, facilitating access to markets, and increasing efficiency by increasing competition. See Fisher \& Lande, supra note 19. 
faulted. The question, rather, is whether the Division's innovative way of defining markets is warranted. The Guidelines convert a compelling insight-that a market ought to be a configuration in which market power might be amassed-into a conduct test, and a hypothetical one at that. A market is provisionally defined im a conventional way. Then one asks hypothetical questions of market actors. Customers in the market, and suppliers in adjacent markets, are asked what they would do if prices in the market were to rise. The Guidelines do not indicate whether these hypothetical questions are only liypothetically asked. Most commentators in this Symposium seem to assume that the questions and answers remaim part of an imternal dialogue in the mind of a Division analyst-informed, perhaps, by readily available historical price and shipments data.

Harris and Jorde assert that the Guidelines' approach will lead to excessively broad market definitions, thus understatimg competitive effects. ${ }^{42}$ They stress lack of attention to imstitutional realities. For example, they point out that total output or capacity in the provisional market will be biased upward simce all output of all firms capable of competing in the provisional market will be imcluded in the denominator for which the HHI is computed, without reference to factors that may as a practical matter subtract large parts of that output or capacity. ${ }^{43}$ They also underscore that the Guidelines' procedure sweeps aside information problems by assuming costless imstantaneous knowledge of the price increase. ${ }^{44}$ Finally, they remark that the hypothetical test may give the appearance of empirical validity to what is likely to be, at its best, an honest guess about such things as cross-elasticities of demand between the provisionally defined product market and a series of possible substitute products. ${ }^{45}$

Much depends, I think, on how those using the Guidelines' methodology regard it. If, in their view they now possess a systematic way of refining judgment and making it more rigorous, the dangers that Harris and Jorde poimt to are very real. At the opposite extreme, a Division analyst might see the methodology as no more than a metaphor to explaim the kinds of imtuitions that go into a pragmatic and holistic judgment about market definition. If those using the Guidelines tend to view the methodology metaphorically, not much will have been illuminated, but neither will much have been changed.

If the methodology is treated as more than a metaphor-and no doubt some will so treat it-the problems seen by Harris-Jorde and

\footnotetext{
42. Harris \& Jorde, supra note 22, at 486.

43. Id. at $479-81$.

44. Id. at $481-82$.

45. Id. at 484.
} 
others are raised. One such problem, discussed by Ordover and Willig, has to do with the way the Guidelines deal with supply substitutability ${ }^{46}$ It is obviously appropriate, and consistent with the case law, to consider this factor. The way in which it is considered is important, however, especially in the context of Guidelines that have fixed, quantitative thresholds. It would not matter greatly whether one defined a golf cart market or a small vehicle market that also included snowmobiles and other such devices, if one considered the significance of alternative formulations when evaluating the significance of the concentration data. Thus, if two golf cart makers are about to merge, existing snowmobile capacity signifies less-perhaps far less-about their power than does existing golf cart capacity, since the ability to produce snowmobiles does not constitute an immediate threat to golf cart manufacturers. There will mevitably be some delay in inoving capacity froin the production of one product to another. There will also be some limit to the extent to which capacity in one product field can be shifted to another. As Baker and Blumenthal stress, ${ }^{47}$ the Guidelines call attention to such issues. However, by building substitutability into market definition, the Guidelines may magnify the reaction to matters about which there is little data. Moreover, if one is operating with norms that specify points at which inergers trigger antitrust concern, there is a danger that alternative market formulations will be ignored.

I have an additional concern. It is that the hypothetical responses to a hypothetical price change will be bolstered with an inevitably inadequate empirical base. The Guidelines virtually invite proponents of a questionable inerger to generate survey research data to enlarge the apparent confines of their market. ${ }^{48}$ But such data will present several problems. First, data from customers will be intrimsically unreliable, even if the survey team strains not to bias the results. Customers will probably be reluctant to admit that they would accept a $5 \%$ price increase without going to a substitute supplier. Second, survey data from both customers and suppliers in adjacent markets could be easily manipulated to support desired results. Third, if the Division is presented with survey data justifying a broadening of the market on the demand side, it will be difficult to resist application of the Guidelines' norms on the grounds that the technologies used by suppliers of substitutes differ froin that of suppliers in the provisional market, and that firms in the provisional market are already earning supracompetitive

46. Ordover \& Willig, supra note 33 , at 563-64.

47. Baker \& Blumenthal, supra note 12, at 328.

48. A possible and collateral effect of the Guidelines will be to increase the tendency evident already annong litigators to use marketing professors, skilled at framing survey questionnaires, instead of economists as experts on market definition. 
returns. ${ }^{49}$ In this respect the failure of the Guidelines to take explicit account of the significance of the relationship between cross-elasticity of demand and the level of returns that current prices are yielding will prove at best an enibarrassment and, at worst, a cause of error.

\section{Discretion Under the Guidelines}

As Areeda, ${ }^{50}$ Kauper, ${ }^{51}$ Scliwartz ${ }^{52}$ and Harris-Jorde ${ }^{53}$ remmd us, the Division, by setting forth a list of additional factors-entry conditions, continuities and discontmuities between markets, and otherspurports to retain flexibility. It may challenge a merger when thresholds are not exceeded or withhold challenge when they are. The Guidelines' catalog, though no more revealing than the case law, is at least no more obscure. After all, concentration ratios stand im the case law only as the basis for a presuniption. ${ }^{54}$ A prima facie case based on concentration alone can be rebutted on the basis of a more comprehensive analysis of the niarket. ${ }^{55}$

Yet the Guidelines, by failing to elucidate the manner in which this broad discretion may be exercised, leave a hiatus. If the Division purports to exercise this discretion with any frequency, the value of the Guidelines as a guide to conduct is reduced. If, as is also a possibility, the Division's list of factors are seldom explicitly relied on (though perliaps utilized sub rosa to alter market definitions) the Guidelmes, though seemingly an aid to prediction, are subjcct to many of the criticisms made in these articles.

Indeed, the nrost telling criticism one can make of the Guidelines is that an opportunity to attaim greater clarity, certainty, and predictability may have been lost. The major problems for lawyers and courts in antitrust have to do witl inediating between the analytical concepts of economic theory and the operational concepts of the marketplace. With effort, it is possible to move from the kinds of mformation and ways of conceptualizing that are actually encountered im the market-

49. Harris \& Jorde, supra note 22 , at $483-84$, call attention to the widely recognized fact, ignored in the Guidelines, that while high cross-elasticity of deinand at competitive prices between two products signifies that they should be included in the same market, high cross-elasticity at the point where one of the products is earning supracompetitive returns has no such significance. This has long been recognized in the literature, see Turner, Antitrust Policy and the Cellophane Case, 70 HARV. L. REV. 281, 308-13 (1956), and early on was implicitly recognized by Judge Learned Hand in United States v. Corn Prods. Ref. Co., 234 F. 964, 975-76 (S.D.N.Y. 1916), appeal dismissed on motion of counsel, 249 U.S. 621 (1919).

50. Areeda, supra note 8 , at 309.

51. Kauper, supra note 12, at 508-09.

52. Schwartz, supra note 6, at 595-96.

53. Harris \& Jorde, supra note 22 , at 469.

54. United States v. Philadelphia Nat'l Bank, 374 U.S. 321, 363-65 (1963).

55. See United States v. General Dynamics Corp., 415 U.S. 486, 498 (1974). 
place to the kinds of judgments that sound antitrust policy requires. Providing the techniques and intermediate concepts for this transition is a task that antitrust scholarship has only begun to take up. The Harris-Jorde article deinonstrates the possibilities in the area of nnarket definition. ${ }^{56}$ It is unfortunate that the Guidelines did not attempt this task more generally, rather than staking out only the microanalytic terrain, often in the form of generalities that preserve flexibility but do httle to facilitate attainment of values like clarity and predictability.

To be sure, as Schwartz stresses, the Guidelines are not law. ${ }^{57}$ They need not constrain courts considering the legahity of mergers actually challenged. Nor is the Division the only antitrust enforcer. Thus, courts could reject some challenges made under the Guidelines. Also, some inergers could be successfully challenged by private parties with standing even though the Division, applying the Guidelines, did not challenge the mergers, or even actively imtervened on the side of the defendants. Yet, Schwartz is also clearly right that the Guidelines well may, ${ }^{58}$ and Areeda is probably right that the Guidelines surely will, ${ }^{59}$ influence not only market actors but also the FTC and the courts. The Guidelines suggest the terms of debate for future merger cases. Though they leave much to the intuition and policy choices of the Division, and thus need not of themselves greatly reduce the discretion of future Division chiefs, they will influence the developing law if only by their influence on the general climate of opinion about mergers. By changing the terms of the debate they alter the agenda and, at least to some extent, the options of all who deal with antitrust.

\section{III}

\section{Vertical MERgers}

Despite their contribution to early merger jurisprudence, vertical inergers have never loomed large as an enforcement target. Williamson summarizes the now conventional analytical view about such mergers-the "new consensus" to which he has been a major contributor. ${ }^{60}$ While he praises the Guidelines for incorporating insights from the new consensus, he criticizes them for obscuring their own substantive thrust and perhaps unduly downgrading the significance of vertical

56. Harris \& Jorde, supra note 22, at 493-96. See also Harris \& Sullivan, Passing on the Monopoly Overcharge: A Comprehensive Policy Analysis, 128 U. PA. L. REv. 269 (1979), which demonstrates the feasibility of tracing the flow of an overcharge through a distribution chain by linking a theoretic analysis of data based on the operational concepts of the marktplace.

57. Schwartz, supra note 6 , at 583.

58. Id. at 576.

59. Areeda, supra note 8, at 306.

60. Williamson, Vertical Merger Guidelines: Interpreting The 1982 Reforms, 71 CALIF. L. REv. 604, 615-17 (1983). 
inergers by incorporatimg them with other non-horizontal mergers and not discussing thein separately.

Williainson regards the Guidelines as expressing a substantial shift in policy ${ }^{61}$ in that vertical mergers will be viewed critically only in concentrated markets. Baker and Blumenthal, by contrast, see the Guidelines as resuscitatimg vertical enforcement to some degree. ${ }^{62}$ Actually, even in the early years of section 7 few vertical mergers were challenged by the Division except where the merger also had horizontal eleinents. ${ }^{63}$ Indeed, so far as I am aware, the Division never challenged a nerger in an unconcentrated market solely on vertical grounds. In any event, it is now widely accepted that im some circumstances integration is an efficient way to link two vertical levels. It does no violence to existing law to say that such mergers ordinarily ought not to be challenged, absent either a foreclosure tending to increase entry barrier or a loss of significant potential competition $\mathrm{m}$ a concentrated market.

The risk, in sum, is not that there will be overly aggressive enforcement agamst vertical mergers. The risk, rather, is that the Guidelines may solidify the now-conventional attitude to such an extent that Division analysts will fail to register the significance of vertical relationships even when these are likely to be troublesome. For example, the proposed acquisition of Marathon by Mobil, with a planned spimoff of Marathon's downstream assets to Amerada-Hess, might pass muster under Guideline norms. Yet, $\mathrm{m}$ an imdustry in which all major producers are vertically integrated and also coordinate inany of their activities through joint ventures, such a merger might seriously reduce access by independents to refined products. ${ }^{64}$

IV

\section{MARKet EXTENSION MERgers}

Market extension mergers which may have horizontal impacts receive attention under the rubric of "potentional competition"- -a mode of analysis that is also relevant to some vertical mergers. Brodley finds fault with current judicial analysis of potential competition problems, but applauds the Guidelines for restoring vitality to potential competition enforceinent. ${ }^{65}$ I wonder whether it is his wish that breeds his word. The Guidelines' structural categories-market concentration, entry conditions, relative entry advantage, and target market share-

61. Id. at 609 .

62. Baker \& Blumenthal, supra note 12, at 312 .

63. See, e.g., Brown Shoe Co. v. United States, 370 U.S. 294 (1962).

64. Adams, Mega-Mergers Spell Danger, Challenge, Mar.-Apr. 1982, at 12.

65. Brodley, Potential Competition Under the Merger Guidelines, 71 CALIF. L. Rev. 376, 376 (1983). 
strike me as conceptually consistent with what one finds in the cases, includimg the cases that Brodley criticizes. ${ }^{66}$ The significant enforcement question is less a matter of choosing concepts than of using them. I find nothing in the Guidelines to challenge iny assumption that the Division is likely to be no more aggressive than the courts have recently been in applying these concepts to nuarket extension inergers.

Change, to the extent implicit, may well move the other way. For one thing, the tendencies identified by Harris and Jorde ${ }^{67}$ inay lead to expansive market definitions. If so, many mergers that might, under pre-Guidelines' standards, have appeared to present niarket extension or potential competition problems, will be subsumed under the horizontal analysis of seemingly unconcentrated markets. For another, much of Brodley's optimism comes from his own tour-de-force in giving meaning to the Guidelines' crucial, yet undefined, concept, "entry advantage."' they ought to be, and if entry advantage were evaluated as Brodley thinks it ought to be, and if the Guidelines were then followed by the Division with success in the courts, the consequence would be better decisions im potential competition cases. All that is a consumunation to be desired, but little im the record of the Division to date invites confidence that it will move off in the direction to which Professor Brodley is pointing.

\section{$\mathrm{V}$ \\ Conglomerate Mergers}

The Guidelines take the now-orthodox view that purely conglomerate inergers present no competitive problem. Professor Bauer regards this as unfortunate. ${ }^{69}$ It is difficult, however, to make the case that the Division's position is inconsistent with soine of the case law. Save for an enforcement effort by the Division during the Nixon administration ${ }^{70}$-an effort that, however one might appraise it from an antitrust perspective, was unarred by radiations fronı Watergate ${ }^{71}$-there has been a broad consensus that mergers that do not increase market concentration or give rise to other analytically identifiable competition

66. See, e.g., United States v. Marine Bancorp., 418 U.S. 602 (1974), criticized in Brodley, supra note 65 , at $378-81$.

67. Harris \& Jorde, supra note 22, at 486.

68. Brodley, supra note 62 , at $390-96$.

69. Bauer, Government Enforcement Policy of Section 7 of the Clayton Act: Carte Blanche for Conglomerate Mergers?, 71 CALIF. L. Rev. 348, 351 (1983).

70. E.g., United States v. Ling-Temco-Vought, Inc., 315 F. Supp. 1301 (W.D. Pa. 1970) (consent decree).

71. See, e.g., United States v. ITT, 349 F. Supp. 22 (D. Conn. 1972), affd per curiam sub nom. Nader v. United States, 410 U.S. 919 (1973). 
problems, do not violate section $7 .^{72}$

Bauer then takes on the less straining task of challenging the position on grounds of policy. The arguments why congloinerate mergers on the vast scale that the nation has been witnessing ought to be banned ${ }^{73}$ grow more compelling each year. Adauns attacks them regularly im convimcing fashion. For exainple, focusing on the oil industry he recently asked:

If . . we posit increased oil and gas production and energy independence as a national goal, how is that objective served by Mobil's acquisition of Montgomery Ward . . .; ARCO's acquisition of The London Observer and Anaconda; Exxon's acquisition of Rehance Electric . . . Standard Oil of Ohio's acquisition of Kennecott Copper; Getty's projected entry into home box office television; or the use of Hunt Brothers' oil fortune to speculate in silver? ${ }^{74}$

Questions like this can be asked about unost of the mega-inergers that have been rocking the economy for nearly a decacle. Answers that presuppose the economy to be a frictionless plane are inadequate. There is a relationship between what one gets out of an economy and what one puts into it. If the inajor energies of corporate executives are devoted to initiating and defending against raiding parties, what one is likely to get out of the econoiny is a spectacle, a game of corporate musical chairs. If the saine energies were devoted to cost containment, innovation or new production, the economy could be expected to work better than it does.

Despite the seriousness of the mega-merger problein, one who takes seriously the conjuction between antitrust and law cannot easily fault the Division for not writing Guidelines that challenge congloinerate inergers. If, as I suggested earher, ${ }^{75}$ prosecutorial discretion is not broad enough to warrant a refusal to enforce the Sherman Act against resale price fixing, it is probably not broad enough, either, to warrant making section 7 of Clayton a shield against such mergers. Both matters, as I see it, are part of the pohtics of antitrust; change, if it is to come, ought to come from Congress.

\section{CONCLUSION}

The Guidelines have inany of the qualities of any committee effort to restate the law. Terminology tends to be both broad and conven-

72. There have been legislative challenges to such mergers. In March 1979, for example, Senator Kennedy introduced a bill that would ban some large conglomerate mergers and inhibit others. See S. 600, 96th Cong., 1st Sess. (1979).

73. See, e.g., Bauer, Challenging Conglomerate Mergers Under Section 7 of the Clayton Act: Today's Law and Tomorrow's Legislation, 58 B.U.L. REv. 199, 245 (1978).

74. Adams, supra note 64, at 12.

75. See supra note 6 and accompanying text. 
tional. Many interesting questions receive not answers, but a framework within which debate can be carried on. For all of that, these Guidelines are at inost points closely linked in concept to existing law.

The single most important issue about fealty to law concerns the way the Division defines the markets to which new horizontal thresholds apply. The next most important question concerns the manner in which the Division utilizes the vast discretion warranted by the inany factors other than HHI thresholds that it may take into account. Schwartz states that the function of the Guidelines will be to provide ideological support for decisions on the basis of its intuitive policy commitments. ${ }^{76}$ One must concede at least this much to that view: it is at least as important who is applying the Guidelines as it is who has drafted them.

Yet, even one committed to significant change, as is Baxter, and who can be both the draftsman and the interpreter of antitrust Guidelines, does not operate without constraints. The merger policy articulated by Congress in 1950 has, in the decades since, been laced into the law-an institution with formidable self-preserving capacity. It was precisely the difference between the ideological attitudes that swirl about antitrust and the legal core of antitrust to which Hofstadter was referring when he wrote, "[i]nstitutions are commonly less fragile than creeds." 77

There are limits to the extent to which any administration can pump its own political attitudes into antitrust. Even when an adininistration is pushing its own views as aggressively as is this one, changes in antitrust tend to occur as do changes in other areas of judge-made law-at a modest pace and in a nianner, often even in directions, seldonı adequately foreseen. For example, courts may prove more coinmitted to thresholds found in the case law, and to values of interest to Congress, but not to Chicago theorists, than are the Guidelines. Courts may be nore ready than are the Guidelines to utilize techniques being developed by mstitutional econonists that help to ground theoretical insights upon operational concepts used by market actors. Yet one can never be confident about such predictions. Courts could abdicate even more than they have in the past to the pohicy views of each incumbent administration, so that antitrust tends to shift with changing political ascendencies. We must suppose that Baxter's Guidelines will be with us for awhile. If they are still in place in 1990 when the antitrust centennial is celebrated, the meanings they then possess will be different from the nreanings the commentators in this Symposium find in them today. By then, merger law will likely be as different from the

76. Schwart, supra note 6 , at 576 .

77. R. HOFSTADTER, supra note 6 , at 228. 
plans that Mr. Baxter has for it today as is the law of today from the plans Mr. Turner expressed for it in 1968. 